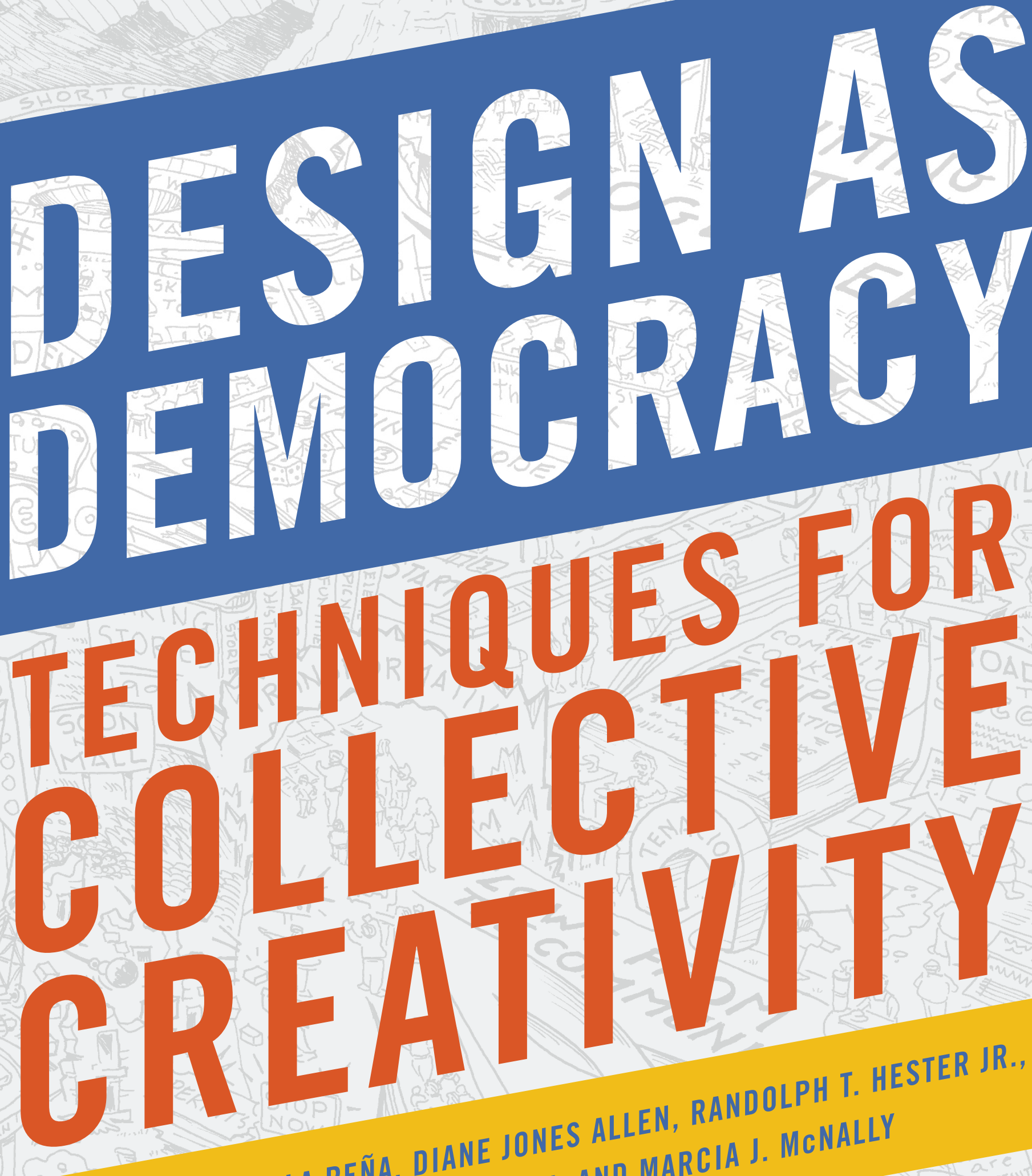
JEFFREY HOU, LAURA J. LAWSON, AND MARCIA J. 



\section{About Island Press}

Since 1984, the nonprofit organization Island Press has been stimulating, shaping, and communicating ideas that are essential for solving environmental problems worldwide. With more than 1,000 titles in print and some 30 new releases each year, we are the nation's leading publisher on environmental issues. We identify innovative thinkers and emerging trends in the environmental field. We work with world-renowned experts and authors to develop cross-disciplinary solutions to environmental challenges.

Island Press designs and executes educational campaigns in conjunction with our authors to communicate their critical messages in print, in person, and online using the latest technologies, innovative programs, and the media. Our goal is to reach targeted audiences-scientists, policymakers, environmental advocates, urban planners, the media, and concerned citizenswith information that can be used to create the framework for long-term ecological health and human well-being.

Island Press gratefully acknowledges major support of our work by The Agua Fund, The Andrew W. Mellon Foundation, The Bobolink Foundation, The Curtis and Edith Munson Foundation, Forrest $\mathrm{C}$. and Frances H. Lattner Foundation, The JPB Foundation, The Kresge Foundation, The Oram Foundation, Inc., The Overbrook Foundation, The S.D. Bechtel, Jr. Foundation, The Summit Charitable Foundation, Inc., and many other generous supporters.

The opinions expressed in this book are those of the author(s) and do not necessarily reflect the views of our supporters. 


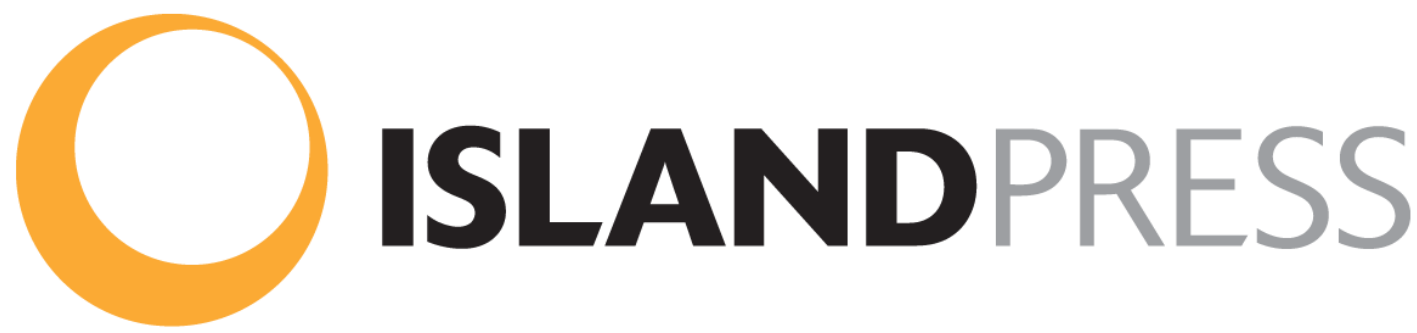

Island Press' mission is to provide the best ideas and information to those seeking to understand and protect the environment and create solutions to its complex problems. Join our newsletter to get the latest news on authors, events, and free book giveaways. Click here to join now! 
DESIGN AS DEMOCRACY 



\title{
DESIGN AS DEMOCRACY
}

\section{Techniques for Collective Creativity}

\author{
edited by \\ David de la Peña \\ Diane Jones Allen \\ Randolph T. Hester Jr. \\ Jeffrey Hou \\ Laura J. Lawson \\ Marcia J. McNally
}

\section{Oislandpress}


Copyright @ 2017 David de la Peña, Diane Jones Allen, Randolph T. Hester Jr., Jeffrey Hou, Laura J. Lawson, and Marcia J. McNally

All rights reserved under International and Pan-American Copyright Conventions. No part of this book may be reproduced in any form or by any means without permission in writing from the publisher: Island Press, 2000 M Street, NW, Suite 650, Washington, DC 20036

Island Press is a trademark of The Center for Resource Economics.

Keywords: advocacy, analysis, assessment, budgeting, collaboration, community engagement, conflict, creativity, design, dialogue, diversity, empathy, empowerment, environmental justice, equity, ethics, evaluation, grassroots, implementation, improvement, local knowledge, mobilize, negotiation, network, organizing, participation, participatory design, partnership, perspective, photography, playground, politics, postconstruction analysis, power, public process, responsibility, sea level rise, sketching, structural change, teamwork, transformation, values, vision, workshop

Library of Congress Control Number: 2017940666

All Island Press books are printed on environmentally responsible materials.

Manufactured in the United States of America

109877654321 


\section{Contents}

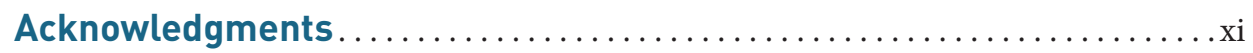

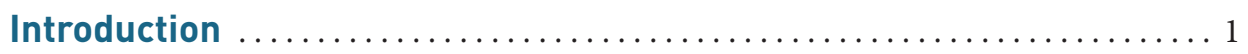

Chapter 1: Suiting Up to Shed. . . . . . . . . . . . . . . . . . . . . 9

What's in It for Us? Designing a Durable Team. Julie Stevens ............... 11

I Am Someone Who. Randolph T. Hester Jr........................ 17

Challenging the Blank Slate. Sungkyung Lee and Laura J. Lawson............ 21

Environmental Autobiography Adaptations. Marcia J. McNally and

Laura J. Lawson. . . . . . . . . . . . . . . . . . . . . . . . . ............ 26

Finding Yourself in the Census. Marcia J. McNally ................. 32

Consume, Vend, and Produce. Marcia J. McNally .................. 37

Chapter 2: Going to the People's Coming ...................... 45

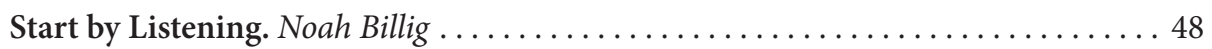

Village Talk. Hala Nassar and Paul Duggan ...................... 52

Community Camera: Piga Picha. Chelina Odbert and Joe Mulligan ............ 56

Sketching Together. Richard Alomar.............................. 60

El Carrito: Rolling Out the Cart. Javier Fraga Cadórniga and David de la Peña . . . . . 64

Pop Up Meeting. Amanda Lovelee. . . . . . . . . . . . . . . . . . . . . 68 
Chapter 3: Experting: They Know, We Know, and Together We Know Better, Later. . . . . 73

Cellphone Diaries: Asset Mapping with Mobile Technology. Kofi Boone ....... 77

Mining the Indigenous. Austin Allen .......................... 83

The Investigative Reporter. Patsy Eubanks Owens .................... 87

Reflect, Articulate, Project (R.A.P.) Method for Sharing Community Stories.

C. L. Bohannon and Terry Clements.......................... 91

Adults Designing Playgrounds by Becoming Children. Yeun-Kum Kim ........ 95

Chapter 4: Calming and Evoking $\ldots \ldots \ldots \ldots \ldots \ldots \ldots \ldots \ldots \ldots \ldots \ldots \ldots \ldots \ldots \ldots \ldots$

Mapping the Common Living Sphere. Kota Maruya . . . . . . . . . . . . . . . . . . 104

Visual Timeline. Sibyl Diver . . . . . . . . . . . . . . . . . . . . . . . . . . . . . . . . . . . 109

Children's Exciting Neighborhood Exploration Event. Isami Kinoshita. . . . . . . 115

Community Innovation Forum. Christian Dimmer and Yu Ohtani .......... 122

The Big Map. Chao-Ching Yu . . . . . . . . . . . . . . . . . . . . . . . 128

Chapter 5: "Yeah! That's What We Should Do".................... 133

Prioritizing Decisions. Maren King. .............................. 136

Community Voting, Local Committees. Sago Network. . . . . . . . . . . . . . . . . 140

Getting a Gestalt. Randolph T. Hester Jr........................ 146

In-House Aha! Marcia J. McNally ............................. 152

Renkei Method: Scaling Up by Connecting Scenes. Yoko Tsuchiya and Masato Dohi ........................................ 158

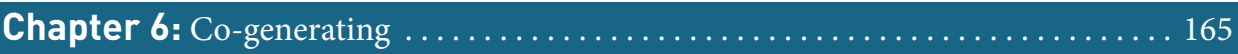

Drawing Out the Sacred, Upside Down. Randolph T. Hester Jr.............. 169

Green Rubber Stamp. ChenYu Lien ........................... 173

Design Buffet. Jeffrey Hou. ................................. 178

Place It Workshop. James Rojas . . . . . . . . . . . . . . . . . . . . . 182

Picture Collage Game. Hideaki Shimura, Kousuke Masuo, and Shigeru Satoh . . . . . 185

Designing Life. Shin Aiba, Jing Jin, Akihiro Soga, and Hirotaka Ikeda . . . . . . . . 189 
Chapter 7: Engaging the Making ............................ 195

Start with Building. Alex Gilliam. .............................. 199

Early Success through Banner Making. Milenko Matanovic............... 203

Pallet Furniture. Lauren Elder ................................ 207

La Maqueta: Interactive Model for Studying and Imagining the City. Andrés Martínez de la Riva Díaz ................................. 211

Cross-Cultural Prototyping. Kofi Boone ....................... 215

Design/Build Service Learning Studio. Daniel Winterbottom .............. 219

Chapter 8: Testing, Testing, Can You Hear Me? Do I Hear You Right?. . . . . . . . 225

The Spatial Design Game: A Design Game That Teaches and Tests.

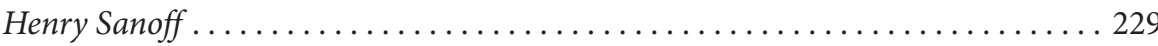

Anticipated Archetypes and Unexpected Idiosyncracies.

Randolph T. Hester Jr. .................................... 233

Raise Your Own Sea Level. Victoria Chanse ...................... 239

Machizukuri: Visualizing Sequential Futures. Naomi Uchida and

Shigeru Satoh........................................... 244

Preemptive Comparison. Randolph T. Hester Jr........................ 249

Participatory Budgeting. Emily Risinger and Sara Egan ................ 256

Chapter 9: Putting Power to Good Use, Delicately and Tenaciously. . . . . . . . . 261

Mapping Environmental Injustice. Randolph T. Hester Jr. . . . . . . . . . . . . 265

Kitchen Table Work Session. Diane Jones Allen . . . . . . . . . . . . . . . . . . . . . . 270

Power Mapping. Randolph T. Hester Jr.......................... 274

Positioning Yourself on the Spectrum of Power and Privilege.

Shalini Agrawal and Shreya Shah ........................... 283

Build Small, Think Structural Change. Laura J. Lawson. .................. 286

Conflict in Its Time and Place. Randolph T. Hester Jr................. 290

Organizing a Place-Based Campaign. Randolph T. Hester Jr............... 296

Conclusion ................................................ 303

Contributor Biographies ................................. 309 



\section{Acknowledgments}

As a book on participatory design techniques, it has required, among a host of things, active participation and thoughtful contributions from many people. We are indebted to each and every one.

We begin by thanking our families, who have inspired us by their creative actions, provided insights by their inquisitiveness, and enforced participatory decision making within our own households. They also patiently supported us when we left town for editor meetings, worked over holidays to get a draft out, and yammered in general about what we were learning in the process. Thankfully, they also kept our feet on the ground, reminding us that this kind of commitment to participation must be balanced with our larger lives. We thank you.

Beyond our immediate families, our extended family of community designers helped at critical points. A number of colleagues at CELA (Council of Educators in Landscape Architecture), EDRA (Environmental Design Research Association), ASLA (American Society of Landscape Architects), and the Pacific Rim Community Design Network offered encouraging support, timely criticism, and connections to community designers we didn't know. Many of the techniques included in the book came from members of these organizations.

This book would not have materialized if so many people from around the world hadn't enthusiastically contributed techniques and responded to our comments and suggestions. Thank you. Your work, some familiar, some new to us, provided the raw material for active debate and deliberation as we worked on the organization and big ideas of the book. We hope you are as excited about the result as we are. 
Chip Sullivan, you are amazing. It was a great pleasure to be on the inside of your drawing process. We are thrilled with your drawings. They bring life and brilliance to our work in a way that only you know how to do. Thank you.

Our university departments and affiliations have provided us with the financial, collegial, and staff assistance needed to have three face-to-face work retreats and to print the book in color. We are grateful to the School of Environmental and Biological Sciences at Rutgers University; the Department of Landscape Architecture and Environmental Planning at the University of California, Berkeley, including the Student Community Design Fund and the Beatrix Farrand Fund; the Office of Research and the College of Agricultural and Environmental Sciences at the University of California, Davis; and the Department of Landscape Architecture at the University of Washington, Seattle.

We are also grateful to our students and the young people with whom we have worked in professional offices. Many of you have been involved in the creation and shaping of our participatory techniques. Similarly, we thank those of you who, as community members and clients, have tested the utility of the techniques we include in the book.

And finally, we would like to thank Island Press. Courtney Lix, you inspired us with your commitment to the project as well as performing the first edit and helping us navigate the title and cover. Elizabeth Farry, you kept us organized and have been amazing at keeping all of our contributors on the straight and narrow. Sharis Simonian, we have been lucky to have you at the production helm. Thank you and everyone at the press for recognizing the importance of design as democracy and bringing the book to life. 



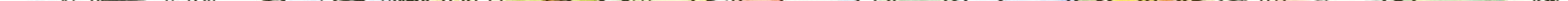

